\title{
Assessment of Copper and Zinc in Soils of a Vineyard Region in the State of São Paulo, Brazil
}

\section{Gláucia Cecília Gabrielli dos Santos, ${ }^{1}$ Gustavo Souza Valladares, ${ }^{2}$ Cleide Aparecida Abreu, Otávio Antônio de Camargo, ${ }^{1}$ and Célia Regina Grego ${ }^{3}$}

\author{
${ }^{1}$ Instituto Agronômico de Campinas, Avenida Barão de Itapura 1481, 13012-970 Campinas, SP, Brazil \\ ${ }^{2}$ UFC/CCA, Departament de Ciências do Solo, Campus do Pici, Bloco 807, 12168, 60021-970 Fortaleza, CE, Brazil \\ ${ }^{3}$ Embrapa Monitoramento por Satélite, Avenida Soldado Passarinho 303, Fazenda Chapadão, 13070-115 Campinas, SP, Brazil \\ Correspondence should be addressed to Cleide Aparecida Abreu; cleide@iac.sp.gov.br
}

Received 7 March 2013; Revised 16 July 2013; Accepted 20 August 2013

Academic Editor: María Cruz Díaz Álvarez

Copyright (c) 2013 Gláucia Cecília Gabrielli dos Santos et al. This is an open access article distributed under the Creative Commons Attribution License, which permits unrestricted use, distribution, and reproduction in any medium, provided the original work is properly cited.

\begin{abstract}
This soil acidification may increase the bioavailability of copper $(\mathrm{Cu})$ and zinc $(\mathrm{Zn})$ in soils. The objective of this study was to verify the concentrations of $\mathrm{Cu}$ and $\mathrm{Zn}$ in soils of a vineyard region, including sample acidification, to simulate acid rain. The study was developed in an area of vineyard cultivation, with an adjacent land having other crops grown, in the state of São Paulo, Brazil. Soil samples were collected and GPS located under different uses and coverings. The extracted solutions used to determine the available $\mathrm{Cu}$ and $\mathrm{Zn}$ forms were diethylenetriaminepentaacetic acid (DTPA), pH 7.3, and calcium chloride $0.01 \mathrm{M}$. The total forms were obtained by $\mathrm{HNO}_{3}$ digestion. The amounts of $\mathrm{Cu}$ and $\mathrm{Zn}$ extracted using DTPA were considered high in most of the samples and were greater in the areas cultivated with vineyards that had received fungicide applications for several decades. The total forms were higher in vineyard soils. The amounts of $\mathrm{Cu}$ and $\mathrm{Zn}$ extracted using $\mathrm{CaCl}_{2}$ did not have good correlation with vineyards or with other metals' forms. The results confirmed that the soil was enriched with $\mathrm{Cu}$ and $\mathrm{Zn}$ due to the management of the vineyards with chemicals for several decades.
\end{abstract}

\section{Introduction}

Soil conservation is fundamental for the sustainable development and preservation of ecosystems and biodiversity. The soil is exposed to contamination through several anthropic activities, mainly agriculture. The contamination of soil by heavy metals results in a high risk of its productive capacity and of the balance of the ecosystems [1].

Soil has a diverse heavy-metal concentration that is dependent on the parent material from which it is formed, the formation processes, and the composition and proportion of the components of the solid phase [2]. This concentration may be affected by several anthropic activities, including irrigation, fertilizer and chemical applications, and industrial or urban sewage incorporation $[3,4]$. Moreover, the concentration, distribution, and bioavailability of heavy metals in the environment are influenced by the soil type, topography, geology, and erosive processes [5].
Cultivation may cause soil contamination by heavy metals, specifically copper in vineyard areas $[1,6,7]$. The intensive use of agrochemicals with $\mathrm{Cu}$ and $\mathrm{Zn}$ in their composition may pollute the soil [8-10]. Historical and current applications have resulted in $\mathrm{Cu}$ accumulation in the soil, and total $\mathrm{Cu}$ quantities have been measured in vineyards worldwide. High concentrations of fungicide-derived copper in orchard and vineyard soils have been reported from around the world, for example, Brazil, 36-3,215 $\mathrm{mg} \mathrm{kg}^{-1}$ [11]; Champagne/France, $100-1,500 \mathrm{mg} \mathrm{kg}^{-1}$ [12]; India, $29-131 \mathrm{mg} \mathrm{kg}^{-1}$ [13]; and Australia, 1-223 mg kg-1 [14]. It has been suggested that areas with greater humidity and precipitation, such as Brazil or Champagne, France, exhibit higher $\mathrm{Cu}$ concentrations than dry environments, due to higher $\mathrm{Cu}$ use [10].

The acidification of soil and surface water is a serious concern in society today [15-17]. The acid rain and resulting soil acidification are a real problem in São Paulo state due to 
TABLE 1: Descriptive statistics of soil attributes in the vineyard and other uses in the region studied.

\begin{tabular}{|c|c|c|c|c|c|c|c|c|c|}
\hline \multirow{2}{*}{ Variable } & \multirow{2}{*}{ Unit } & \multicolumn{4}{|c|}{ Vineyard } & \multicolumn{4}{|c|}{ Other uses } \\
\hline & & Minimum & Maximum & Average & STD & Minimum & Maximum & Average & STD \\
\hline Organic matter & $\mathrm{gL}^{-1}$ & 17.0 & 55.0 & 34.4 & 10.9 & 13.0 & 82.0 & 33.0 & 14.2 \\
\hline CEC & cmolc L $^{-1}$ & 6.07 & 31.2 & 12.2 & 6.49 & 4.55 & 15.1 & 8.05 & 2.64 \\
\hline Base saturation & $\%$ & 37.0 & 95.0 & 67.5 & 16.8 & 10.0 & 93.0 & 42.9 & 21.0 \\
\hline Clay & $\mathrm{g} \mathrm{kg}^{-1}$ & 150 & 313 & 223 & 41.8 & 125 & 450 & 254 & 66.9 \\
\hline Silt & $\mathrm{g} \mathrm{kg}^{-1}$ & 75.0 & 226 & 142 & 38.7 & 74.0 & 243 & 154 & 41.7 \\
\hline Sand & $\mathrm{g} \mathrm{kg}^{-1}$ & 562 & 729 & 635 & 41.9 & 346 & 788 & 591 & 82.9 \\
\hline $\mathrm{CuT}$ & $\mathrm{mg} \mathrm{kg}^{-1}$ & 10.0 & 40.5 & 20.7 & 8.41 & 4.65 & 80.3 & 13.4 & 11.7 \\
\hline $\mathrm{ZnT}$ & $\mathrm{mg} \mathrm{kg}^{-1}$ & 14.3 & 243 & 53.4 & 43.0 & 6.48 & 225 & 45.7 & 40.2 \\
\hline $\mathrm{pH} \mathrm{CaCl}{ }_{2}$ & & 4.20 & 6.50 & 5.16 & 0.62 & 3.70 & 6.40 & 4.70 & 0.63 \\
\hline $\mathrm{pH} \mathrm{CaCl}{ }_{2}$ after acidified & & 3.63 & 6.97 & 4.96 & 0.92 & 3.33 & 6.60 & 4.31 & 0.70 \\
\hline CuDTPA & $\mathrm{mg} \mathrm{kg}^{-1}$ & 2.80 & 15.5 & 6.79 & 3.27 & 1.30 & 15.4 & 2.69 & 2.18 \\
\hline CuDTPA after acidified & $\mathrm{mg} \mathrm{kg}^{-1}$ & 2.59 & 22.1 & 9.11 & 4.89 & 1.26 & 20.0 & 3.47 & 2.82 \\
\hline ZnDTPA & $\mathrm{mg} \mathrm{kg}^{-1}$ & 4.80 & 25.0 & 11.8 & 5.63 & 1.40 & 24.8 & 5.39 & 4.75 \\
\hline ZnDTPA after acidified & $\mathrm{mg} \mathrm{kg}^{-1}$ & 5.02 & 29.9 & 13.7 & 6.47 & 0.97 & 28.0 & 5.64 & 5.37 \\
\hline $\mathrm{CuCaCl}$ & $\mathrm{mg} \mathrm{kg}^{-1}$ & 0.01 & 0.12 & 0.08 & 0.03 & 0.01 & 0.61 & 0.06 & 0.10 \\
\hline $\mathrm{CuCaCl}$ after acidified & $\mathrm{mg} \mathrm{kg}^{-1}$ & 0.03 & 0.08 & 0.05 & 0.01 & 0.02 & 1.23 & 0.07 & 0.19 \\
\hline $\mathrm{ZnCaCl}$ & $\mathrm{mg} \mathrm{kg}^{-1}$ & 0.01 & 2.58 & 0.73 & 0.73 & 0.01 & 8.97 & 1.17 & 1.67 \\
\hline $\mathrm{ZnCaCl}$ after acidified & $\mathrm{mg} \mathrm{kg}^{-1}$ & 0.01 & 3.11 & 1.37 & 1.11 & 0.03 & 4.54 & 1.09 & 1.05 \\
\hline
\end{tabular}

STD: standard deviation.

the intense industrialization [18], and the soils in the region studied here are considered the most sensitive to acidification in Brazil [19].

Statistical and geostatistical techniques can assist in the interpretation of research in soil pollution by heavy metals $[1,20,21]$.

The objective of this study was to verify the concentrations of $\mathrm{Cu}$ and $\mathrm{Zn}$ in the soils of a vineyard region, including the acidification of the samples, with the objective of simulating acid rain.

\section{Materials and Methods}

The study was performed in a 59.8 ha catchment area in Jundiaí, São Paulo state, Brazil $\left(23^{\circ} 11^{\prime} \mathrm{S}, 46^{\circ} 53^{\prime} \mathrm{W}\right)$, which is occupied by 2.9 ha vineyard (Figure 1) that is ten to sixty years old, has natural vegetation, pastures, and other types of orchards in the vicinity, and is $672-755 \mathrm{~m}$ altitude. The landscape is rolling and hilly in a geomorphological province that is dominated by a "half-orange" type of relief. The soil types in the area are inceptisols, ultisols, and oxisols [22], and the main original rock is the schist. The descriptive statistics of soil attributes are presented in Table 1.

The spatial data were uniform made and were GPS located based on satellite images with high-spatial resolution. An interpretation of land use and cover was made with detailed field checking based on an IKONOS II mosaic (orbital point 159539, on July 4, 2001, at 13:19 PM and on November 08, 2001, at 13:24 PM). The land use/land cover map and the topographic data were utilized to plan the soil sampling, ultimately establishing a total of one hundred sample points. These points were georeferenced and integrated in a vectorial format in the geographic information system (GIS).

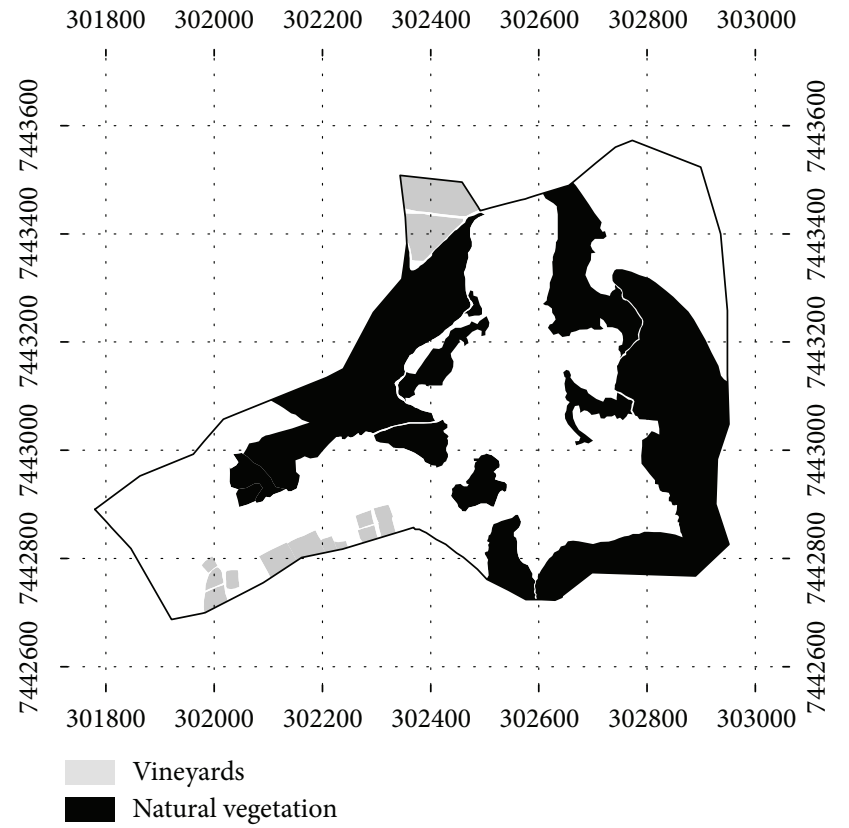

FIGURE 1: Area of study in a vineyard region of São Paulo state, Brazil.

At this stage, the area was traversed. With the help of an auger, 67 georeferenced perturbed soil samples at $0-0.15 \mathrm{~m}$ depth were collected, including 37 from the vineyard and 30 from the land under other crops grown. The samples were air dried, crushed, and passed through a $2 \mathrm{~mm}$ sieve.

The 67 soil samples ( $100 \mathrm{~g}$ each), after being dried and sieved, were assembled in glass percolation columns and treated with $20 \mathrm{~mL}$ of $\mathrm{HNO}_{3} 0.1 \mathrm{~mol} \mathrm{~L}^{-1}$ and $100 \mathrm{~mL}$ of 
deionized water to eliminate the $\mathrm{H}+$ excess and alter their $\mathrm{pH}$, as described by Camargo and Raij [23]. The samples were incubated for 15 days for a complete acidification reaction and were then dried, sieved, and chemically analyzed for the bioavailability of $\mathrm{Cu}$ and $\mathrm{Zn}$. The $\mathrm{CuT}$ and $\mathrm{ZnT}$ concentrations were determined using $\mathrm{HNO}_{3}$ according to the procedure described in the U.S. EPA 3051 method [24]; the available form was determined using DTPA pH 7.3 (CuDTPA and $\mathrm{ZnDTPA}$ ) [25] and $\mathrm{CaCl}_{2} 0.01 \mathrm{~mol} \mathrm{~L}^{-1}(\mathrm{CuCaCl}$ and $\mathrm{ZnCaCl})[6,26]$ extractions. The $\mathrm{Cu}$ and $\mathrm{Zn}$ levels in the digestion extracts were determined by ICP-OES.

A descriptive statistical analysis was used for calculation. The discriminate analysis (DA) is a method of dependence analysis and is a special case of canonical correlation. In this study, the DA was first used to reveal whether the land use patterns differed significantly in terms of $\mathrm{Cu}$ and $\mathrm{Zn}$ concentrations. To analyze the spatial variability, the geostatistical analysis $[27,28]$ was used through the elaboration and adjustment of semivariograms and data interpolation by kriging for mapping.

\section{Results and Discussion}

3.1. General Soil Characteristics. The physicochemical characteristics and element contents are summarized in Table 1. The selected soils were naturally acidic to slightly acidic $\left(1 \mathrm{M} \mathrm{CaCl}_{2} \mathrm{pH}\right.$ range 3.7-6.5), with an average value of 5.1, with textures that varied from loam (common in soils developed from schist or slate) to sandy loam (typical for granite soils). The soil samples taken in this region had large sand contents (346-788 $\mathrm{g} \mathrm{kg}^{-1}$ ), and the loam or sandy loam textures that are typical of soils were developed over granites.

Cation exchange capacities (CEC) ranged from 6.07 to $31.2 \mathrm{cmol}_{\mathrm{c}} \mathrm{L}^{-1}$ (Table 1). The highest values of CEC were found in vineyard soil.

Soil organic matter contents were generally high but varied widely, ranging from 13 to $82 \mathrm{gL}^{-1}$ (Table 1). The soil organic matter content is useful to give an idea of the texture of the soil, with values up to $15 \mathrm{~g} \mathrm{~L}^{-1}$ for sandy soils, between 16 and $30 \mathrm{~g} \mathrm{~L}^{-1}$ for medium texture and $31-60 \mathrm{~g} \mathrm{~L}^{-1}$ for clay soils. Values above $60 \mathrm{gL}^{-1}$ indicate the accumulation of organic matter in the soil, generally by poor drainage or high acidity. The highest values of organic matter were found in forest soils $\left(82 \mathrm{~g} \mathrm{~L}^{-1}\right)$ and vineyard soils $\left(55 \mathrm{~g} \mathrm{~L}^{-1}\right)$.

3.2. Total $\mathrm{Cu}$ and $\mathrm{Zn}$ Concentrations. The total $\mathrm{Cu}$ content in the vineyard and in soil under other uses in the region varied between 10 and $40.5 \mathrm{mg} \mathrm{kg}^{-1}$ and between 4.7 and $80.3 \mathrm{mg} \mathrm{kg}^{-1}$, respectively (Table 1 ).

The total $\mathrm{Cu}$ values are generally higher than or similar to those reported by Kabata-Pendias and Pendias [29] for natural soils, whose typical values ranged from 13 to $24 \mathrm{mg} \mathrm{kg}^{-1}$, depending on the soil type. On the other hand, the total $\mathrm{Cu}$ values are generally lower than or similar to those reported by Brun et al. [26] in Southern France ( 30 to $250 \mathrm{mg} \mathrm{kg}^{-1}$ ) and by Fernández-Calviño et al. [7] in the Northwest Iberian Peninsula (25 to $666 \mathrm{mg} \mathrm{kg}^{-1}$ ). The differences could reflect different application rates as well as different physical and chemical parameters in the soils, but we do not have enough information to discern diverse possibilities.

The total $\mathrm{Zn}$ content in the vineyard and in soil under other uses in the region varied between 14.3 and $243 \mathrm{mg} \mathrm{kg}^{-1}$ and between 6.48 and $225 \mathrm{mg} \mathrm{kg}^{-1}$, respectively (Table 1). The total $\mathrm{Zn}$ values are generally higher than or similar to those reported by Alloway [30] for natural soils, whose typical values ranged from 10 to $300 \mathrm{mg} \mathrm{kg}^{-1}$, depending on the soil type. Only $25 \%$ of samples exceeded the average $\mathrm{Zn}$ concentrations reported by Alloway [30] for soils $\left(50 \mathrm{mg} \mathrm{kg}^{-1}\right)$. The total $\mathrm{Zn}$ values are generally higher than or similar to those reported by Fernández-Calviño et al. [31] in vineyard soils (60 to $149 \mathrm{mg} \mathrm{kg}^{-1}$ ).

The total concentrations of $\mathrm{Cu}$ and $\mathrm{Zn}$ in the area compared to the soil reference values $\left(\mathrm{mg} \mathrm{kg}^{-1}\right)$ from São Paulo state range from 35 to $60 \mathrm{mg} \mathrm{kg}^{-1}$ and from 60 to $300 \mathrm{mg} \mathrm{kg}^{-1}$ [32], respectively. It was observed that only three topsoil samples $(3 \%)$ had a concentration higher than the reference value for $\mathrm{Cu}$ and that only one sample presented a concentration higher than the prevention values. The higher total $\mathrm{Cu}$ concentrations were observed in soils under vineyard, palm, and Typha. The area with palm had previously been cultivated with vineyards for decades, and the soil under Typha vegetation represents a wetland that is in a lower altitude position of the study area, which most likely received contaminated sediments from the higher parts of the landscape. These results clearly demonstrate the risk of contaminating the adjacent areas and the power of $\mathrm{Cu}$ permanency in the soil.

Because many vineyards are located on steep slopes, intensive erosion furtherly influences $\mathrm{Cu}$ mobility in these soils and thus increases the risks associated with groundwater contamination.

The effect of landscape on copper levels in soils is unclear. Sediments in Galicia (Spain) river valley were found to have higher copper levels than nearby vineyard soils [33]. Rusjan et al. [34] found that amongst plains, plateaus, and terraces, copper levels were highest on terraces.

The copper content in vineyard soils is attributed to factors such as frequency of pesticide application and local climatic conditions. Studies from France and Italy demonstrate that vineyard soils in wet regions contain more copper than in dry regions [26, 35]. Deluisa et al. [35] attributed this effect to differences in soil type and precipitation, the latter encouraging greater use of copper. However, Pietrzak and McPhail [36] did not see a difference in copper application between humid regions and drier regions. The vineyards situated in the region where humid climate dominates (Gippsland region) generally do not receive greater annual application of copper-based fungicides than vineyards located in subhumid conditions (Rutherhglan region). The local factors of each vineyard (e.g., slope, exposure, amount of sun received, surrounded vegetation, and wind breakers) play important roles in controlling any outbreaks of diseases and at the same time influence the use of fungicides. Other authors have suggested that erosion, leaching, and plowing are the main determinants [37]. 
For the $\mathrm{Zn}$ total concentration, 14 topsoil samples (21\%) presented concentrations higher than the reference values in both vineyard and soil used to grow pears. These results indicate that agricultural management contributed to soil contamination with $\mathrm{Cu}$ and $\mathrm{Zn}$.

3.3. Available $\mathrm{Cu}$ and $\mathrm{Zn}$ Concentrations and Soil Attributes. Although the total $\mathrm{Cu}$ and $\mathrm{Zn}$ soil concentrations are a fair indication of availability, including deficiency or oversupply, they do not provide conclusive information about the environmental impact of this availability. The $\mathrm{Cu}$ and $\mathrm{Zn}$ availability to the biota, when used as nutrients or toxic elements, and their mobility are important factors to consider when investigating the effect of these metals on the environment. In this context, the available concentrations of $\mathrm{Cu}$ and $\mathrm{Zn}$ seem to be the best indicator to make inferences about the potential environment impacts of these elements.

The concentrations of $\mathrm{Cu}$ and $\mathrm{Zn}$ extracted using DTPA may provide information about the elements' availability for plant nutrition [38] and their potential to pollute the soil [39]. The $\mathrm{Cu}$ concentration in topsoil varied from 1.3 to $15.5 \mathrm{mg} \mathrm{kg}^{-1}$, with a mean of $4.3 \mathrm{mg} \mathrm{kg}^{-1}$ (CuDTPA), and from 0.01 to $0.61 \mathrm{mg} \mathrm{kg}^{-1}$, with a mean of $0.06 \mathrm{mg} \mathrm{kg}^{-1}(\mathrm{CuCaCl})$ (Table 1$)$. The highest concentrations of $\mathrm{Cu}$ extracted using DTPA occurred in soils under the same use as that used to obtain the total $\mathrm{Cu}$. However, for $\mathrm{Cu}$ extraction with $\mathrm{CaCl}_{2}$, the highest $\mathrm{Cu}$ concentration which occurred in soils under experimental vineyards differs from the highest total and DTPA $\mathrm{Cu}$ concentrations which occurred in experimental and commercial vineyards.

The $\mathrm{Zn}$ concentration in topsoil varied from 1.4 to $25.0 \mathrm{mg} \mathrm{kg}^{-1}$, with a mean of $8.1 \mathrm{mg} \mathrm{kg}^{-1}$ (ZnDTPA), and from 0.01 to $8.97 \mathrm{mg} \mathrm{kg}^{-1}$, with a mean of $1.0 \mathrm{mg} \mathrm{kg}^{-1}$ $(\mathrm{ZnCaCl})$ (Table 1). The higher concentration of available $\mathrm{Zn}$ occurred in soils under vineyards and natural vegetation, indicating that the high available $\mathrm{Zn}$ concentration may be explained by anthropogenic pollution. Despite the application of agrochemicals, the same finding was observed for the total $\mathrm{Zn}$, that is, the natural concentration of the element once it also occurs in some natural vegetation land uses (Table 1).

According to Student's $t$-test $(P<0.05)$, topsoils in vineyards had higher concentrations of the total form of $\mathrm{Cu}$ as well as that extracted by DTPA and $\mathrm{CaCl}_{2}$ than did the other land uses. The same result was observed for $\mathrm{Zn}$ extracted by DTPA but not for $\mathrm{Zn}$ extracted by $\mathrm{CaCl}_{2}$ or for its total form. These results show a reasonable soil contamination in vineyard areas by $\mathrm{Cu}$ and a probable elevation in the available Zn concentration.

The average concentrations of available forms of $\mathrm{Cu}$ and $\mathrm{Zn}$ in vineyard soils tend to be higher than the concentrations observed in soils under other uses, with exception of $\mathrm{CaCl}_{2}$ extractable $\mathrm{Cu}$ and $\mathrm{Zn}$, where the higher mean concentrations (1.23 and $\left.4.54 \mathrm{mg} \mathrm{kg}^{-1}\right)$ were observed in soils under natural vegetation (Table 1 ).

Generally, the vineyard soils have higher $\mathrm{pH}$ and CEC than what is observed in soils under other uses. High CEC encourages metals to bind with soil aggregates, depending on the organic matter and the clay content of the soil. High $\mathrm{pH}$ enhances the dissociation of organic acids and, therefore, the formation of complexes with metals, altering metal speciation and reducing bioavailability [40].

3.4. Available Forms of Cu and Zn after Acidification. Considering all of the surface samples acidified (Table 1), there is a slight increase in $\mathrm{Cu}$ content in the soil, which ranged from 1.26 to $22.1 \mathrm{mg} \mathrm{kg}^{-1}$, with a mean of $5.7 \mathrm{mg} \mathrm{kg}^{-1}$ (CuDTPA), and from 0.02 to $1.23 \mathrm{mg} \mathrm{kg}^{-1}$, with a mean of $0.06 \mathrm{mg} \mathrm{kg}^{-1}$ $(\mathrm{CuCaCl})$. As observed in the natural, nonacid samples, the maximum values of $\mathrm{Cu}$ were found in areas that were occupied by vineyards and Typha.

The soil acidification revealed higher concentrations of DTPA-extractable $\mathrm{Cu}$ and $\mathrm{Zn}$, which were not observed for $\mathrm{CaCl}_{2}$-extractable $\mathrm{Cu}$ and $\mathrm{Zn}$. These results indicate that the DTPA method was more sensitive to soil acidification for simulating acid rain than was $\mathrm{CaCl}_{2}$. These results disagree with those obtained by Brun et al. [26] that indicated the $\mathrm{CaCl}_{2}$ extractant as the best for the available forms of $\mathrm{Cu}$ in vineyard soils. Such disagreement is probably due to differences between the original $\mathrm{pH}$ of these soil regions.

The statistical method used to compare the $\mathrm{Cu}$ and $\mathrm{Zn}$ concentrations extracted both with and without acidification was linear regression $(Y=b 0+b 1 X)$, as suggested by J. C. Miller and J. N. Miller [41]. The null hypotheses were that the declivity ( $b 1)$ would not be different from one (1) and that the intercept $(b 0)$ would not be different from zero (0). These hypotheses were tested by calculating the confidence limits at $95 \%$ for both coefficients. The results were also submitted to an analysis of variance ( $F$-test) and to correlation.

According to the regression analyses of $\mathrm{Cu}$ and $\mathrm{Zn}$ extracted by DTPA, the intercept is equal to zero (0), and the angular coefficient is higher than the unit (1). These results indicate that the acidification promoted more metal extraction (Table 2). Then, the soil acidification increased the availability of $\mathrm{Cu}$ and $\mathrm{Zn}$, thus increasing the risk of environmental contamination. Moreover, in Jundiai, an undulated relief is predominant $[22,42]$, and the soil erosion potential is high which is reflected by the slope and, in some cases, the texture gradient of the ultisols. In this landscape, erosion may thus transport sediments that have been contaminated with $\mathrm{Cu}$ to the lower regions, thus increasing the environmental impact of $\mathrm{Cu}$ contamination. Excessive amounts of hydrogen ions, introduced into the soil by acid rain or fertilization, can release $\mathrm{Cu}$ through cation exchange. The metal mobilized in the soil can thus eventually enter aquatic systems through rainwater or can enter groundwater, rivers, and lakes. Rivers draining cultivated areas with high soil $\mathrm{Cu}$ concentrations can also have high $\mathrm{Cu}$ concentrations [43]. In the case of vineyard soils, which are the most easily eroded cultivated soils [44], applied $\mathrm{Cu}$ can reach water bodies not only in water-soluble forms but also, due to erosion, in colloidbound forms that can accumulate below the water body in sediments. In vine growing areas, evaluating the risk of water quality that is posed by the use of copper-based fungicides therefore requires determining the $\mathrm{Cu}$ levels and the distribution of $\mathrm{Cu}$ among its more and less bioavailable forms in both vineyard soils and the sediments of local water bodies. 
TABLE 2: Regression coefficients for the available forms of $\mathrm{Cu}$ and $\mathrm{Zn}$ extracted by DTPA and $\mathrm{CaCl}_{2}$; natural (independent variable) and acidified (dependent variable) samples.

\begin{tabular}{|c|c|c|c|c|c|c|c|c|c|}
\hline \multirow{2}{*}{ Element/method } & \multirow{2}{*}{$r^{2}$} & \multicolumn{3}{|c|}{ Intercept } & \multirow{2}{*}{$P$} & \multicolumn{3}{|c|}{ Angular coefficient } & \multirow{2}{*}{$P$} \\
\hline & & Min. & Average & Max. & & Min. & Average & Max. & \\
\hline CuDTPA & 0.95 & -0.61 & -0.18 & 0.24 & 0.39 & 1.29 & 1.37 & 1.44 & $<0.01$ \\
\hline ZnDTPA & 0.94 & -0.88 & -0.17 & 0.53 & 0.62 & 1.06 & 1.13 & 1.20 & $<0.01$ \\
\hline $\mathrm{CuCaCl}$ & 0,15 & 0.028 & 0.033 & 0.038 & $<0.01$ & 0.053 & 0.126 & 0.200 & $<0.01$ \\
\hline $\mathrm{ZnCaCl}$ & 0.59 & 0.401 & 0.611 & 0.820 & $<0.01$ & 0.480 & 0.605 & 0.730 & $<0.01$ \\
\hline
\end{tabular}

TABLE 3: Correlation coefficients between forms of $\mathrm{Cu}$ and $\mathrm{Zn}$ and other soil attributes.

\begin{tabular}{|c|c|c|c|c|c|c|}
\hline & $\mathrm{CuT}$ & $\mathrm{ZnT}$ & $\begin{array}{l}\text { CuDTPA } \\
\text { acidified }\end{array}$ & $\begin{array}{l}\text { ZnDTPA } \\
\text { acidified }\end{array}$ & $\begin{array}{r}\mathrm{CuCaCl} \\
\text { acidified }\end{array}$ & $\mathrm{ZnCaCl}$ acidified \\
\hline $\begin{array}{l}\text { Organic } \\
\text { matter }\end{array}$ & $0.49^{*}$ & 0.15 & 0.27 & $0.57^{*}$ & 0.12 & -0.28 \\
\hline $\mathrm{pH}$ & $0.37^{*}$ & -0.09 & 0.33 & -0.25 & -0.01 & $-0.87^{*}$ \\
\hline CEC & $0.52^{*}$ & 0.08 & 0.22 & -0.01 & 0.10 & $-0.60^{*}$ \\
\hline $\begin{array}{l}\text { Bases } \\
\text { saturation }\end{array}$ & $0.45^{*}$ & -0.05 & 0.35 & -0.06 & 0.00 & $-0.88^{*}$ \\
\hline CuDTPA & $0.72^{*}$ & $0.52^{*}$ & $0.97^{*}$ & $0.44^{*}$ & 0.14 & -0.18 \\
\hline ZnDTPA & $0.49^{*}$ & $0.63^{*}$ & $0.47^{*}$ & $0.94^{*}$ & 0.06 & 0.25 \\
\hline $\mathrm{CuCaCl}$ & 0.00 & -0.01 & $-0.49^{*}$ & 0.12 & 0.20 & 0.25 \\
\hline $\mathrm{ZnCaCl}$ & -0.16 & 0.22 & -0.25 & 0.37 & 0.11 & $0.88^{*}$ \\
\hline $\mathrm{CuT}$ & 1.00 & $0.54^{*}$ & $0.70^{*}$ & $0.44^{*}$ & 0.20 & -0.29 \\
\hline $\mathrm{ZnT}$ & & 1.00 & $0.47^{*}$ & $0.63^{*}$ & -0.01 & 0.21 \\
\hline $\begin{array}{l}\text { CuDTPA } \\
\text { acidified }\end{array}$ & & & 1.00 & 0.33 & 0.11 & -0.27 \\
\hline $\begin{array}{l}\text { ZnDTPA } \\
\text { acidified }\end{array}$ & & & & 1.00 & 0.06 & 0.23 \\
\hline $\begin{array}{l}\mathrm{CuCaCl} \\
\text { acidified }\end{array}$ & & & & & 1.00 & -0.02 \\
\hline Clay & & & $0.45^{*}$ & -0.17 & -0.24 & -0.18 \\
\hline Silt & & & -0.30 & 0.01 & 0.26 & 0.20 \\
\hline Sand & & & -0.17 & 0.16 & -0.01 & -0.01 \\
\hline
\end{tabular}

The regression analyses of $\mathrm{Cu}$ and $\mathrm{Zn}$ extracted by $\mathrm{CaCl}_{2}$ show that the intercepts are higher than zero $(0)$ and that the angular coefficients are lower than one (1). These results indicate a dual behavior in the samples. Conversely, in samples with low metal concentrations, the acidification increases the concentration of the metals, and in samples with high concentrations, the acidification promoted less extraction.

The $\mathrm{Cu}$ concentration extracted by $\mathrm{CaCl}_{2}$ was compared to soils under either vineyard or other land uses, using Student's $t$-test. For both acidified and nonacidified soils, the $\mathrm{CuCaCl}_{2}$ concentration was higher in vineyard soils, though the difference was greater among the nonacidified soils, with a mean of $0.076 \mathrm{mg} \mathrm{kg}^{-1}$ in vineyard soils and a mean of $0.041 \mathrm{mg} \mathrm{kg}^{-1}$ in soil under other uses. For the acidified soils, the mean in vineyard soils was $0.046 \mathrm{mg} \mathrm{kg}^{-1}$, and it was $0.037 \mathrm{mg} \mathrm{kg}^{-1}$ for soil under other uses; the results were significant at the 0.05 level. For $\mathrm{Zn}$ extracted by $\mathrm{CaCl}_{2}$, the results showed no difference between soils under vineyard or other uses. These results indicate that the $\mathrm{CaCl}_{2}$ method could not efficiently show $\mathrm{Zn}$ contamination by agricultural management: the higher concentrations of $\mathrm{Zn}$ extracted by $\mathrm{CaCl}_{2}$ occurred in soils under natural vegetation, which differ from the $\mathrm{Zn}$ concentrations determined by total $\mathrm{Zn}$ and $\mathrm{Zn}$ extracted by DTPA.

3.5. Relationship between $\mathrm{Cu}$ and $\mathrm{Zn}$ and Soil Attributes. Table 3 presents the correlation coefficients obtained between the $\mathrm{Cu}$ and $\mathrm{Zn}$ total and acidified forms and for the other soil properties in 27 samples of vineyard topsoil. The total $\mathrm{Cu}$ was correlated with soil organic matter $(r=0.49), \mathrm{pH}(r=0.37)$, cation exchange capacity (CEC) $(r=0.52)$, base saturation $(r=0.45)$, CuDTPA $(r=0.72)$, ZnDTPA $(r=0.49)$, and total $\mathrm{Zn}(r=0.54)$, whereas total $\mathrm{Zn}$ was correlated only with CuDTPA $(r=0.52)$ and ZnDTPA $(r=0.63)$.

Brun et al. [26], comparing various soil extractors, observed that $\mathrm{Cu}$ extracted by $0.01 \mathrm{~mol} \mathrm{~L}^{-1} \mathrm{CaCl}_{2}$ was correlated well with the soil pH (i.e., it was decreased with increasing 
TABLE 4: Confusion matrix of land use classifications based on discriminant analysis.

\begin{tabular}{|c|c|c|c|c|}
\hline Land use & To natural vegetation & To nonvineyard & To vineyard & Sum \\
\hline \multirow{2}{*}{ From natural vegetation } & 3 & 2 & 0 & 5 \\
\hline & $60 \%$ & $40 \%$ & $0.00 \%$ & $100 \%$ \\
\hline \multirow{2}{*}{ From nonvineyard } & 0 & 32 & 2 & 34 \\
\hline & $0 \%$ & $94 \%$ & $6 \%$ & $100 \%$ \\
\hline \multirow{2}{*}{ From vineyard } & 0 & 2 & 25 & 27 \\
\hline & $0.00 \%$ & $7 \%$ & $93 \%$ & $100 \%$ \\
\hline Sum & 3 & 36 & 27 & 66 \\
\hline
\end{tabular}

soil $\mathrm{pH}$ ), which is an important property controlling the bioavailability of $\mathrm{Cu}$. However, $\mathrm{Cu}$ extracted by DTPA at $\mathrm{pH}$ 7.3 was correlated only with the CEC.

High positive correlation between CuDTPA and ZnDTPA content, $\mathrm{pH}$, organic matter, and base saturation was found in the same area by Valladares et al. [45] (i.e., the $\mathrm{Cu}$ content increases with increasing $\mathrm{pH}$, organic matter, and base saturation).

Copper in soils is strongly immobilized by the composition of the soil sorption complex $[10,46]$ (i.e., organic matter, $\mathrm{Fe}-, \mathrm{Mn}$-oxyhydroxides, and nature of the humic substances). Soluble humic and fulvic acids may increase the solubility and mobility of the elements; once in a neutral to alkaline reaction environment, they form stable complexes with the carboxyl, hydroxyl, and amino groups of these compounds [46, 47].

The acidified forms of $\mathrm{Cu}$ and $\mathrm{Zn}$ extracted by DTPA were highly correlated with total $\mathrm{Cu}$ and $\mathrm{Zn}$, whereas $\mathrm{Zn}$ DTPA showed a higher correlation with soil organic matter than did $\mathrm{Cu}$. These results differ from those observed in the literature $[46,47]$, which correlates $\mathrm{Cu}$ with soil organic matter. The acidified Cu DTPA was correlated with clay content.

Unlike the $\mathrm{Cu}$ and $\mathrm{Zn}$ forms extracted by DTPA, the behaviors of the acidified forms of $\mathrm{Cu}$ and $\mathrm{Zn}$ that were extracted by $\mathrm{CaCl}_{2}$ were very different. The acidified $\mathrm{Cu}$ extracted by $\mathrm{CaCl}_{2}$ was not correlated with other soil attributes; this result should reflect the $\mathrm{Cu}$ forms that were released by the weathering of shale because the soils are poorly developed in the vineyards (inceptisols). No correlation between acidified and nonacidified $\mathrm{Cu}$ extracted by $\mathrm{CaCl}_{2}$ was observed. The acidified and nonacidified $\mathrm{Zn}$ extracted by $\mathrm{CaCl}_{2}$ had good intercorrelation and were highnegatively correlated with $\mathrm{pH}, \mathrm{CEC}$, and base saturation.

In order to determine whether the three different land uses, native vegetation, vineyard, and other agriculture activities, differed significantly in terms of $\mathrm{Cu}$ and $\mathrm{Zn}$ soil concentrations before and after acidification, discriminate analysis was used. In this way, the three land uses were entered in the calculations as the grouping variables and the soil $\mathrm{Cu}$ and $\mathrm{Zn}$ concentration forms were entered as the independent variables.

The discriminate analysis results are displayed in Figure 2, which present the groups of land uses formed according to the $\mathrm{Cu}$ and $\mathrm{Zn}$ concentrations in soil. The obtained results indicate that the three land uses had different levels of $\mathrm{Cu}$ and $\mathrm{Zn}$ concentrations in the top layer of soil, both before and after acidification. For each extracted element concentration, a high degree of between-groups variation

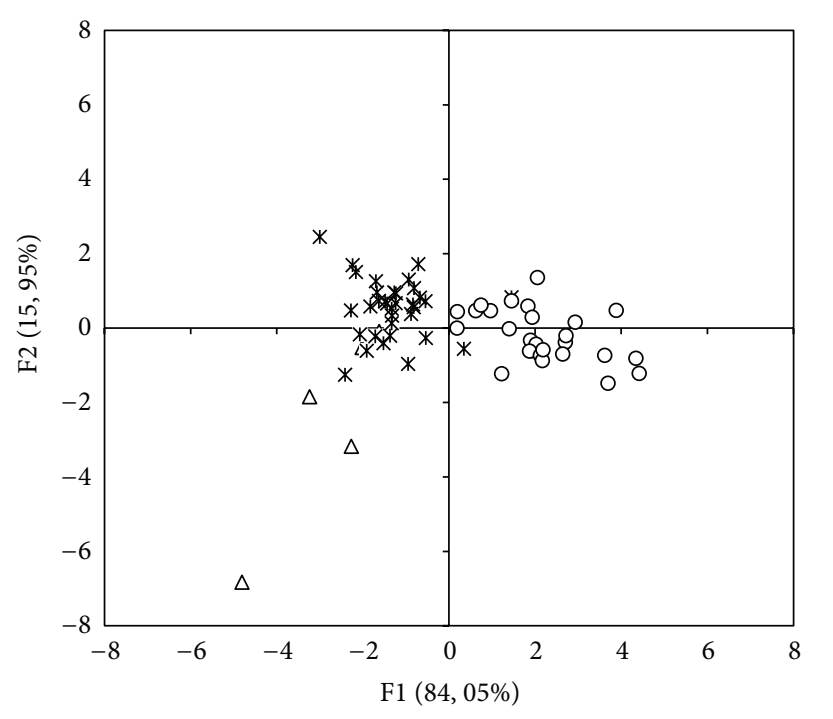

$\Delta$ Natural vegetation
$*$ Nonvineyard
○ Vineyard

FIGURE 2: Factors of discriminant analysis showing land use groups formed according to $\mathrm{Cu}$ and $\mathrm{Zn}$ concentrations in soil.

TABLE 5: Factor loadings generated by discriminant analysis.

\begin{tabular}{lcc}
\hline Variable & $F_{1}$ & $F_{2}$ \\
\hline $\mathrm{CuDTPA}$ & 0.798 & -0.206 \\
$\mathrm{ZnDTPA}$ & 0.510 & -0.642 \\
$\mathrm{CuCaCl}$ & 0.427 & -0.242 \\
$\mathrm{ZnCaCl}$ & -0.301 & -0.853 \\
$\mathrm{CuT}$ & 0.661 & -0.087 \\
$\mathrm{ZnT}$ & 0.124 & 0.172 \\
$\mathrm{CuDTPA}$ acidified & 0.768 & -0.209 \\
$\mathrm{ZnDTPA}$ acidified & 0.559 & -0.586 \\
$\mathrm{CuCaCl}_{2}$ acidified & 0.369 & -0.083 \\
$\mathrm{ZnCaCl}_{2}$ acidified & 0.057 & -0.621 \\
\hline
\end{tabular}

exists, with canonical correlation values varying between 0.63 and 0.88 . The Wilks' lambda statistics indicate that the difference among the land uses is significant at $P=0.05$. The statistically significant results also show a very high percentage of correct classification, ranging from $60 \%$ to $94 \%$ (Table 4). The analysis of Mahalanobis distances indicates a 


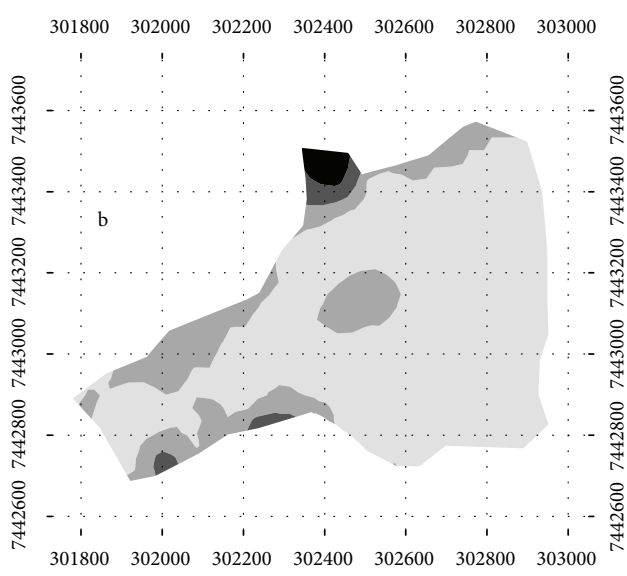
$\mathrm{Cu}\left(\mathrm{mgkg}^{-1}\right)$
$1-3$
$3-6$
6-10

(a)

$\begin{array}{lllllll}301800 & 302000 & 302200 & 302400 & 302600 & 302800 & 303000\end{array}$

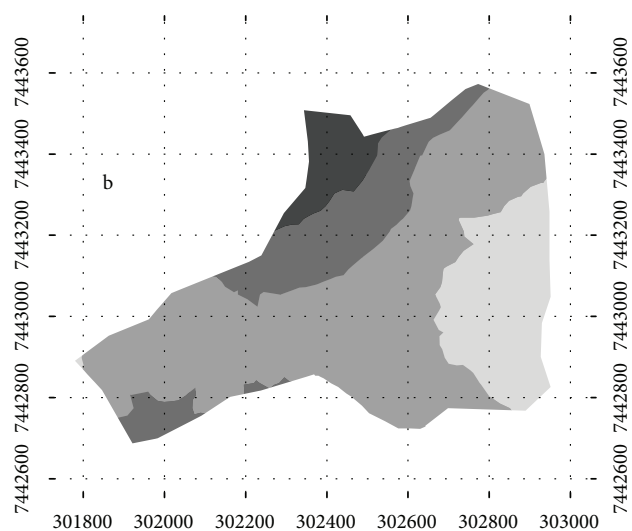
$\mathrm{Zn}\left(\mathrm{mg} \mathrm{kg}^{-1}\right)$
$1-4$
$4-8$

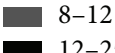

(c)

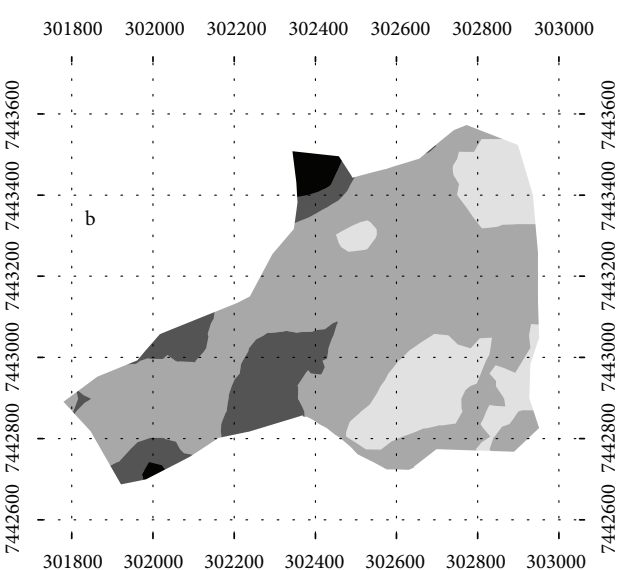

$\mathrm{Cu}\left(\mathrm{mg} \mathrm{kg}^{-1}\right)$
5-10
- 15-20
-10-15
-20-40

(e)

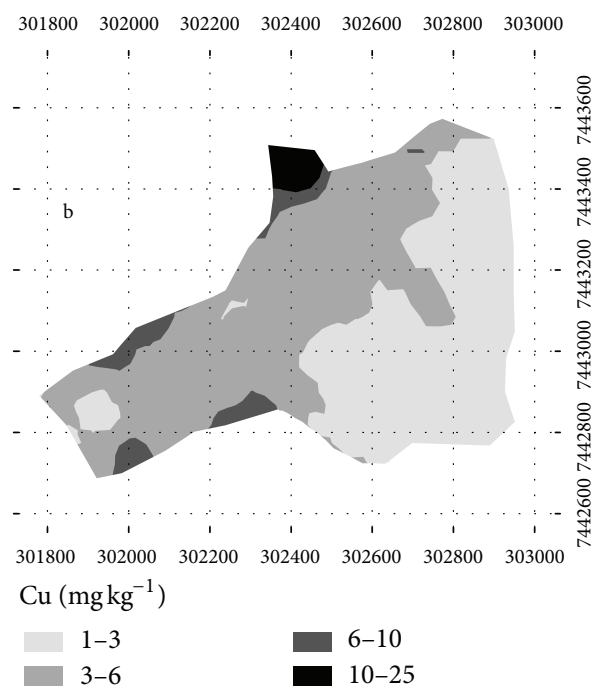

(b)

$\begin{array}{lllllll}301800 & 302000 & 302200 & 302400 & 302600 & 302800 & 303000\end{array}$

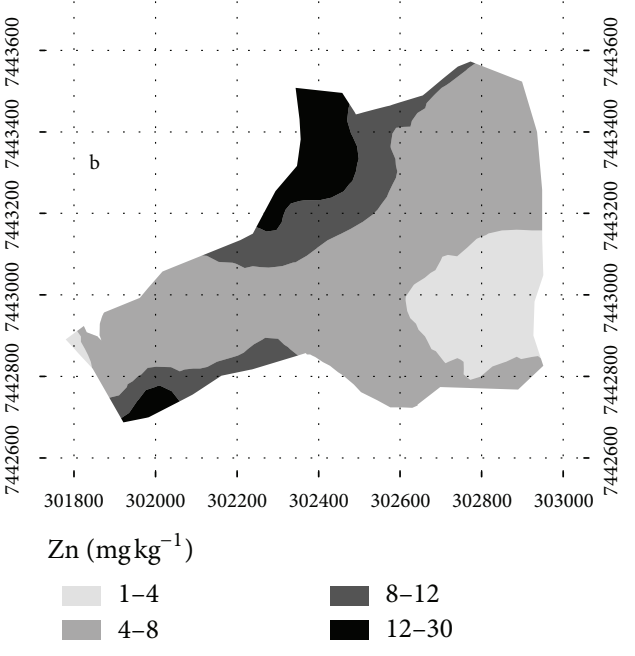

(d)

$\begin{array}{lllllll}301800 & 302000 & 302200 & 302400 & 302600 & 302800 & 303000\end{array}$

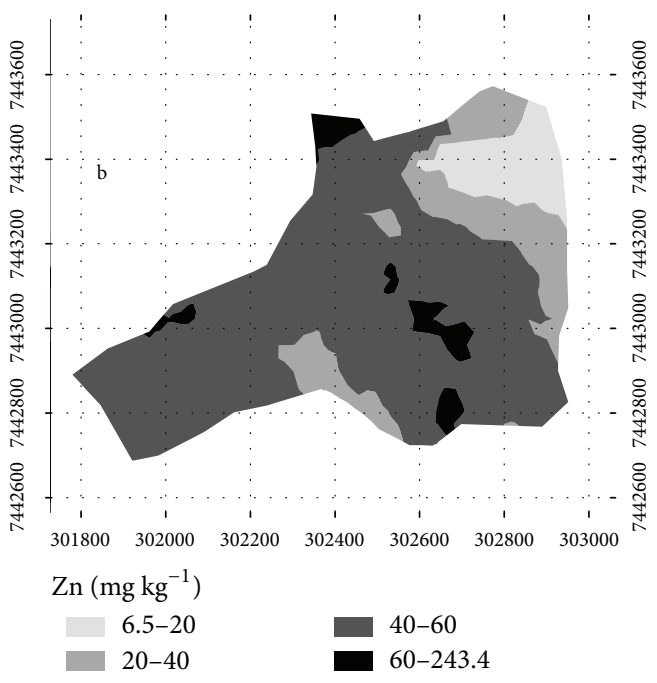

(f)

Figure 3: Continued. 


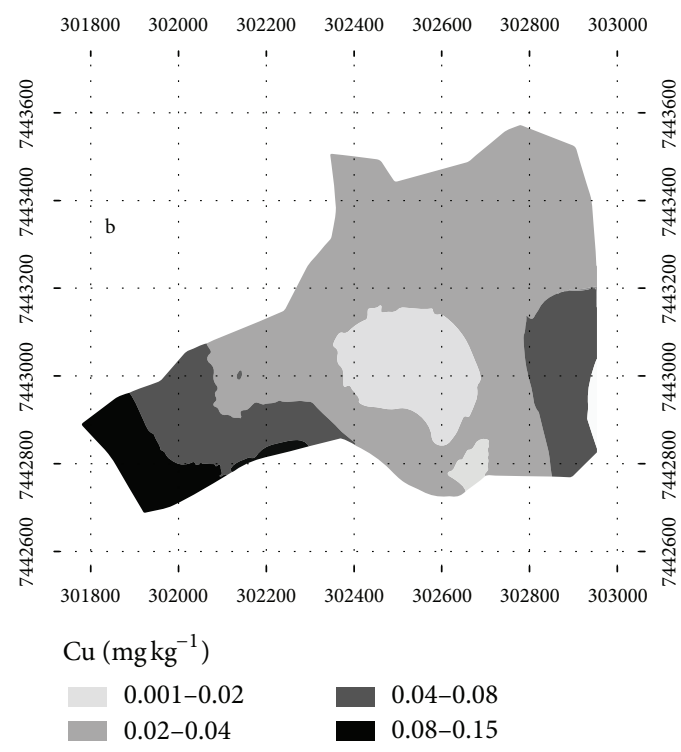

(g)

FIgURE 3: Spatial distributions of the $\mathrm{Cu}$ and $\mathrm{Zn}$ extracted by DTPA and $\mathrm{CaCl}_{2}$ in natural and acidified samples and the total content of $\mathrm{Cu}$ and $\mathrm{Zn}$ in natural soil samples. (a) and (c) $\mathrm{Cu}$ and $\mathrm{Zn}$ extracted by DTPA in natural samples; (b) and (d) Cu and Zn extracted by DTPA in acidified soil samples; (e) and (f) total content of $\mathrm{Cu}$ and $\mathrm{Zn}$ in soil; (g) $\mathrm{Cu}$ extracted by $\mathrm{CaCl}_{2}$ in natural samples.

TABLE 6: Semivariograms parameters for spatial distributions of $\mathrm{Cu}$ and $\mathrm{Zn}$ in soils from a vineyard region of São Paulo state: nugget effect $\left(C_{0}\right)$, sill $(C)$, range $(A)$, and dependency degree (GD).

\begin{tabular}{|c|c|c|c|c|c|}
\hline Variable & $C_{0}$ & $C$ & $A(\mathrm{~m})$ & GD (\%) & Model \\
\hline CuDTPA & 0.94 & 6.85 & 125.8 & 86 & Spherical \\
\hline CuDTPA acidified & 2.36 & 12.80 & 125.6 & 82 & Spherical \\
\hline ZnDTPA & 22.00 & 59.34 & 966.0 & 63 & Gaussian \\
\hline ZnDTPA acidified & 29.70 & 107.40 & 1204.0 & 72 & Exponential \\
\hline $\mathrm{CuT}$ & 51.66 & 102.18 & 290.5 & 49 & Spherical \\
\hline $\mathrm{ZnT}$ & 890.00 & 5890.00 & 1666.0 & 85 & Gaussian \\
\hline $\mathrm{CuCaCl}$ & 0.0008 & 0.0026 & 854.0 & 69 & Spherical \\
\hline $\mathrm{CuCaCl}$ acidified & 0.0002 & 0.0002 & - & - & Nugget effect \\
\hline $\mathrm{ZnCaCl}$ & 0.64 & 0.64 & - & - & Nugget effect \\
\hline $\mathrm{ZnCaCl}$ acidified & 0.13 & 0.13 & - & - & Nugget effect \\
\hline
\end{tabular}

highly significant probability of differences among the land uses, varying from 0.0001 to 0.003 , though vineyard differed from the other land uses more significantly.

Eigenvalues explained $84.05 \%$ of variance in the first factor (Figure 2). Factor loadings generated by the discriminate analysis are presented in Table 5, which shows the groups formed by the metals' forms, indicating correlation among them. The first group with high values for factor 1 is formed by the two forms of $\mathrm{Cu}$ extracted by DTPA and by the total $\mathrm{Cu}$. A second group is formed by the two forms of $\mathrm{Zn}$ extracted by DTPA. These groups indicate the high contaminations of $\mathrm{Cu}$ and $\mathrm{Zn}$ in the vineyard soils. Other forms of the metals did not have good correlations and may thus describe natural high concentrations of these metals. These results confirm the low correlation between the acidified and nonacidified forms of $\mathrm{Cu}$ and $\mathrm{Zn}$ extracted by $\mathrm{CaCl}_{2}$.

Discriminate analysis shows strong differences between the $\mathrm{Cu}$ and $\mathrm{Zn}$ concentrations in the investigated land uses and that the behaviors of the forms are variable.
3.6. Spatial Distribution of $\mathrm{Cu}$ and $\mathrm{Zn}$. Copper and Zinc concentrations extracted by DTPA, which was obtained from 67 topsoil georeferenced samples, both natural and acidified, were analyzed to determine their spatial dependence using geostatistical and semivariograms analyses (Table 6), kriging interpolation of data, and map building isolines. The spatial dependence of the samples was strong for $\mathrm{Cu}$ and moderate for $\mathrm{Zn}$, according to the ratio of spatial dependence (GD) (Table 6). Spherical model for $\mathrm{Cu}$ had a good adjustment, with a nugget effect near 0 (zero). For $\mathrm{Zn}$, the nonacidified soil had the best adjustment using the Gaussian model, and the acidified soil had better adjustment in the exponential model.

A change occurred in the spatial behavior of the $\mathrm{Cu}$ and $\mathrm{Zn}$ concentrations, extracted by DTPA, in natural and acidified samples (Figures 3(a), 3(b), 3(c), and 3(d)), indicating that an occurrence of acid rain or an acid fertilizer reaction would increase the amount of copper available in the area. This effect is even more pronounced in the vineyard 
soils, where an increased $\mathrm{Cu}$ concentration (Figure 1) was observed.

High total $\mathrm{Cu}$ concentration coincides with the areas under vines (Figures 1 and 3(e)). Thus, a risk of contamination may be occurring in these areas. Considering such factors as high $\mathrm{Cu}$ concentrations in vineyard soils, soil acidification, and slope, erosion effects may contaminate the lower lands in the landscape. The total $\mathrm{Zn}$ concentration coincides with vineyards and natural vegetation, indicating a natural high concentration and contamination in the vineyard (Figure 3(f)).

Analyzing spatial dependence of $\mathrm{Cu}$ and $\mathrm{Zn}$ extracted by $\mathrm{CaCl}_{2}$, only nonacidified $\mathrm{Cu}$ had moderate dependence and displayed good adjustment to the spherical model (Figure 3(g)). Acidified extraction of the $\mathrm{Cu}$ and $\mathrm{Zn}$ forms did not show spatial dependence and had verified the "nugget effect." The forms extracted by $\mathrm{CaCl}_{2}$ did not have a spatial correlation with the DTPA and total forms and instead showed different behaviors. These results suggest that $\mathrm{CaCl}_{2}$ extraction was less efficient than DTPA in representing the bioavailability of $\mathrm{Cu}$ and $\mathrm{Zn}$.

\section{Conclusions}

The results confirmed the enrichment of the soil with $\mathrm{Cu}$ and $\mathrm{Zn}$ due to the use and management of the vineyards with chemicals for several decades.

\section{Acknowledgment}

Thanks to CNPq for the PHD grant to the first author.

\section{References}

[1] A. Facchinelli, E. Sacchi, and L. Mallen, "Multivariate statistical and GIS-based approach to identify heavy metal sources in soils," Environmental Pollution, vol. 114, no. 3, pp. 313-324, 2001.

[2] L. R. F. Alleoni, R. B. Borba, and O. A. Camargo, "Metais pesados: da cosmogênese aos solos brasileiros," Tópicos em Ciência do Solo, vol. 4, pp. 1-42, 2005.

[3] F. A. Nicholson, S. R. Smith, B. J. Alloway, C. Carlton-Smith, and B. J. Chambers, "An inventory of heavy metals inputs to agricultural soils in England and Wales," Science of the Total Environment, vol. 311, no. 1-3, pp. 205-219, 2003.

[4] V. Simeonov, J. A. Stratis, C. Samara et al., "Assessment of the surface water quality in Northern Greece," Water Research, vol. 37, no. 17, pp. 4119-4124, 2003.

[5] J. F. G. P. Ramalho, N. M. B. Amaral Sobrinho, and A. C. X. Velloso, "Contaminação da microbacia de Caetés com metais pesados pelo uso de agroquímicos," Pesquisa Agropecuária Brasileira, vol. 35, pp. 1289-1303, 2000.

[6] G. R. Nachtigall, R. C. Nogueirol, L. R. F. Alleoni, and M. A. Cambri, "Copper concentration of vineyard soils as a function of $\mathrm{pH}$ variation and addition of poultry litter," Brazilian Archives of Biology and Technology, vol. 50, no. 6, pp. 941-948, 2007.

[7] D. Fernandez-Calviño, J. C. Nóvoa-Muñoz, M. Diaz-Raviña, and M. Arias-Estévez, "Cooper accumulation and fractionation in vineyard soils from temperate humid zone (NW Iberian Penninsula)," Geoderma, vol. 153, no. 1-2, pp. 119-129, 2009.
[8] M. C. Ramos and M. López-Acevedo, "Zinc levels in vineyard soils from the Alt Penedès-Anoia region (NE Spain) after compost application," Advances in Environmental Research, vol. 8, no. 3-4, pp. 687-696, 2004.

[9] S. K. Gaw, A. L. Wilkins, N. D. Kim, G. T. Palmer, and P. Robinson, "Trace element and $\Sigma$ DDT concentrations in horticultural soils from the Tasman, Waikato and Auckland regions of New Zealand," Science of the Total Environment, vol. 355, no. 1-3, pp. 31-47, 2006.

[10] M. Komárek, E. Čadková, V. Chrastný, F. Bordas, and J. Bollinger, "Contamination of vineyard soils with fungicides: a review of environmental and toxicological aspects," Environment International, vol. 36, no. 1, pp. 138-151, 2010.

[11] N. Mirlean, A. Roisenberg, and J. O. Chies, "Metal contamination of vineyard soils in wet subtropics (southern Brazil)," Environmental Pollution, vol. 149, no. 1, pp. 10-17, 2007.

[12] E. Besnard, C. Chenu, and M. Robert, "Influence of organic amendments on copper distribution among particle-size and density fractions in Champagne vineyard soils," Environmental Pollution, vol. 112, no. 3, pp. 329-337, 2001.

[13] B. R. Prasad, S. Basavaiah, A. Subba Rao, and I. V. Subba Rao, "Forms of copper in soils of grape orchards," Journal of the Indian Society of Soil Science, vol. 32, pp. 318-322, 1984.

[14] A. M. Wightwick, S. A. Salzman, S. M. Reichman, G. Allinson, and N. W. Menzies, "Inter-regional variability in environmental availability of fungicide derived copper in vineyard soils: an Australian case study," Journal of Agricultural and Food Chemistry, vol. 58, no. 1, pp. 449-457, 2010.

[15] K. Ito, Y. Uchiyama, N. Kurokami, K. Sugano, and Y. Nakanishi, "Soil acidification and decline of trees in forests within the precincts of shrines in Kyoto (Japan)," Water, Air, and Soil Pollution, vol. 214, no. 1-4, pp. 197-204, 2011.

[16] Y. Zhao, L. Duan, J. Xing, T. Larssen, C. P. Nielsen, and J. Hao, "Soil acidification in China: is controlling $\mathrm{SO}_{2}$ emissions enough?" Environmental Science and Technology, vol. 43, no. 21, pp. 8021-8026, 2009.

[17] C. J. Stevens, N. B. Dise, and D. J. Gowing, "Regional trends in soil acidification and exchangeable metal concentrations in relation to acid deposition rates," Environmental Pollution, vol. 157, no. 1, pp. 313-319, 2009.

[18] M. C. Forti, A. Carvalho, A. J. Melfi, and C. R. Montes, "Deposition patterns of $\mathrm{SO}_{4}{ }^{2-}, \mathrm{NO}_{3}{ }^{-}$and $\mathrm{H}^{+}$in the Brazilian territory," Water, Air, and Soil Pollution, vol. 130, no. 1-4, pp. 1121-1126, 2001.

[19] A. J. Melfi, C. R. Montes, A. Carvalho, and M. C. Forti, "Use of pedological maps in the identification of sensitivity of soils to acidic deposition: application to Brazilian soils," Anais da Academia Brasileira de Ciencias, vol. 76, no. 1, pp. 139-145, 2004.

[20] A. Qishlaqi, F. Moore, and G. Forghani, "Characterization of metal pollution in soils under two landuse patterns in the Angouran region, NW Iran; a study based on multivariate data analysis," Journal of Hazardous Materials, vol. 172, no. 1, pp. 374384, 2009.

[21] D. Fernandez-Calviño, B. Garrido-Rodríguez, J. E. LópezPeriago, M. Paradelo, and M. Ariaz-Estévez, "Spatial distribution of copper fractions in a vineyard soil," Land Degradation \& Development, 2011.

[22] J. Valadares, I. F. Lepsch, and A. Küpper, "Levantamento pedológico detalhado da Estação Experimental de Jundiaí, SP," Bragantia, vol. 30, no. 2, pp. 337-386, 1971.

[23] O. A. Camargo and B. V. Raij, "Movimento do gesso em amostras de Latossolos com diferentes propriedades eletroquí- 
micas," Revista Brasileira de Ciência do Solo, vol. 13, no. 3, pp. 275-280, 1989.

[24] USEPA, "Environmental Protection Agency. Method 3052: Microwave assisted acid digestion of siliceous and organically based matrices. Washington, 1 CD-ROM," 1996, http://www.epa .gov/SW-846/pdfs/3052.pdf.

[25] B. V. Raij, J. C. Andrade, H. Cantarella, and J. A. Quaggio, Análise Química Para Avaliação da fertilidade de Solos Tropicais, Instituto Agronômico de Campinas, Campinas, Brazil, 2001.

[26] L. A. Brun, J. Maillet, J. Richarte, P. Herrmann, and J. C. Remy, "Relationships between extractable copper, soil properties and copper uptake by wild plants in vineyard soils," Environmental Pollution, vol. 102, no. 2-3, pp. 151-161, 1998.

[27] R. M. Srivastava, "Describing spatial variability using geostatistics analysis," in Geostatistics for Environmental and Geotechnical Applications, R. M. Srivastava, S. Rouhani, and M. V. Cromer, Eds., pp. 13-19, American Society for Testing and Materials, West Conshohocken, Pa, USA, 1996.

[28] S. R. Vieira, "Geoestatística em estudos de variabilidade espacial do solo," in Tópicos em Ciência do Solo, R. F. Novais, V. H. Alvares, Schaefer, and C. E. G. R, Eds., pp. 1-54, Sociedade Brasileira de Ciência do Solo, Viçosa, Brasil, 2000.

[29] A. Kabata-Pendias and H. Pendias, Trace Elements in Soils and Plants, CRC Press LLC, Boca Raton, Fla, USA, 3rd edition, 2001.

[30] B. J. Alloway, "Bioavailability of elements in soils," in Essential of Medical Geology, O. Selinus, B. J. Alloway, A. R. Centeno et al., Eds., pp. 347-372, Springer, Amsterdam, The Netherlands, 2005.

[31] D. Fernández-Calviño, M. Pateiro-Moure, J. C. Nóvoa-Muñoz, B. Garrido-Rodríguez, and M. Arias-Estévez, "Zinc distribution and acid-base mobilisation in vineyard soils and sediments," Science of the Total Environment, vol. 414, pp. 470-479, 2012.

[32] São Paulo Environmental Agency, "Report on standard values for soils and groundwater in the São Paulo State: Cetesb, Brazil," 2005, http://www.cetesb.sp.gov.br/Solo/relatorios/tabela _valores_2005.pdf.

[33] D. Fernández-Calviño, M. Pateiro-Moure, E. López-Periago, M. Arias-Estévez, and J. C. Nóvoa-Muñoz, "Copper distribution and acid-base mobilization in vineyard soils and sediments from Galicia (NW Spain)," European Journal of Soil Science, vol. 59, no. 2, pp. 315-326, 2008.

[34] D. Rusjan, M. Strlič, D. Pucko, and Z. Korošec-Koruza, "Copper accumulation regarding the soil characteristics in SubMediterranean vineyards of Slovenia," Geoderma, vol. 141, no. 1-2, pp. 111-118, 2007.

[35] A. Deluisa, P. Giandon, M. Aichner et al., "Copper pollution in italian vineyard soils," Communications in Soil Science and Plant Analysis, vol. 27, no. 5-8, pp. 1537-1548, 1996.

[36] U. Pietrzak and D. C. McPhail, "Copper accumulation, distribution and fractionation in vineyard soils of Victoria, Australia," Geoderma, vol. 122, no. 2-4, pp. 151-166, 2004.

[37] K. A. Mackie, T. Müller, and E. Kandeler, "Remediation of copper in vineyards-a mini review," Environmental Pollution, vol. 167, pp. 16-26, 2012.

[38] C. A. Abreu, A. S. Lopes, and G. C. G. Santos, "Micronutrientes," in Fertilidade do Solo, R. F. N. Novais, V. H. Alvarez, N. F. Barros, R. L. F. Fontes, R. B. Cantarutti, and J. C. L. Neves, Eds., pp. 645736, Sociedade Brasileira de Ciência do Solo, Viçosa, Brazil, 2007.

[39] C. A. Abreu, B. V. Raij, M. F. Abreu, and A. P. González, "Routine soil testing to monitor heavy metals and boron," Scientia Agricola, vol. 62, no. 6, pp. 564-571, 2005.
[40] R. Maier, I. Pepper, and C. Gerba, Environmental Microbiology, Academic Press, San Diego, Calif, USA, 2000.

[41] J. C. Miller and J. N. Miller, Statistics for Analytical Chemistry, Ellis Horwood, New York, NY, USA, 3rd edition, 1993.

[42] J. B. Oliveira, M. N. Camargo, M. Rossi, and B. Calderano Filho, Mapa Pedológico do Estado de São Paulo, Instituto Agronômico, Campinas, Brazil, 1999.

[43] H. Xue, L. Sigg, and R. Gächter, "Transport of Cu, Zn and Cd in a small agricultural catchment," Water Research, vol. 34, no. 9, pp. 2558-2568, 2000.

[44] G. Pardini and M. Gispert, "Impact of land abandonment on water erosion in soils of the Eastern Iberian Peninsula," Agrochimica, vol. 50, no. 1-2, pp. 13-24, 2006.

[45] G. S. Valladares, E. C. Azevedo, O. A. Camargo, C. R. Grego, and M. C. S. Rastoldo, "Variabilidade espacial e disponibilidade de cobre e zinco em solos de vinhedo e adjacências," Bragantia, vol. 68, no. 3, pp. 733-742, 2009.

[46] J. Wu, L. J. West, and D. I. Stewart, "Effect of humic substances on $\mathrm{Cu}$ (II) solubility in kaolin-sand soil," Journal of Hazardous Materials, vol. 94, no. 3, pp. 223-238, 2002.

[47] M. Schnitzer and S. U. Khan, Humic Substances in the Environment, Marcel Dekker, New York, NY, USA, 1972. 

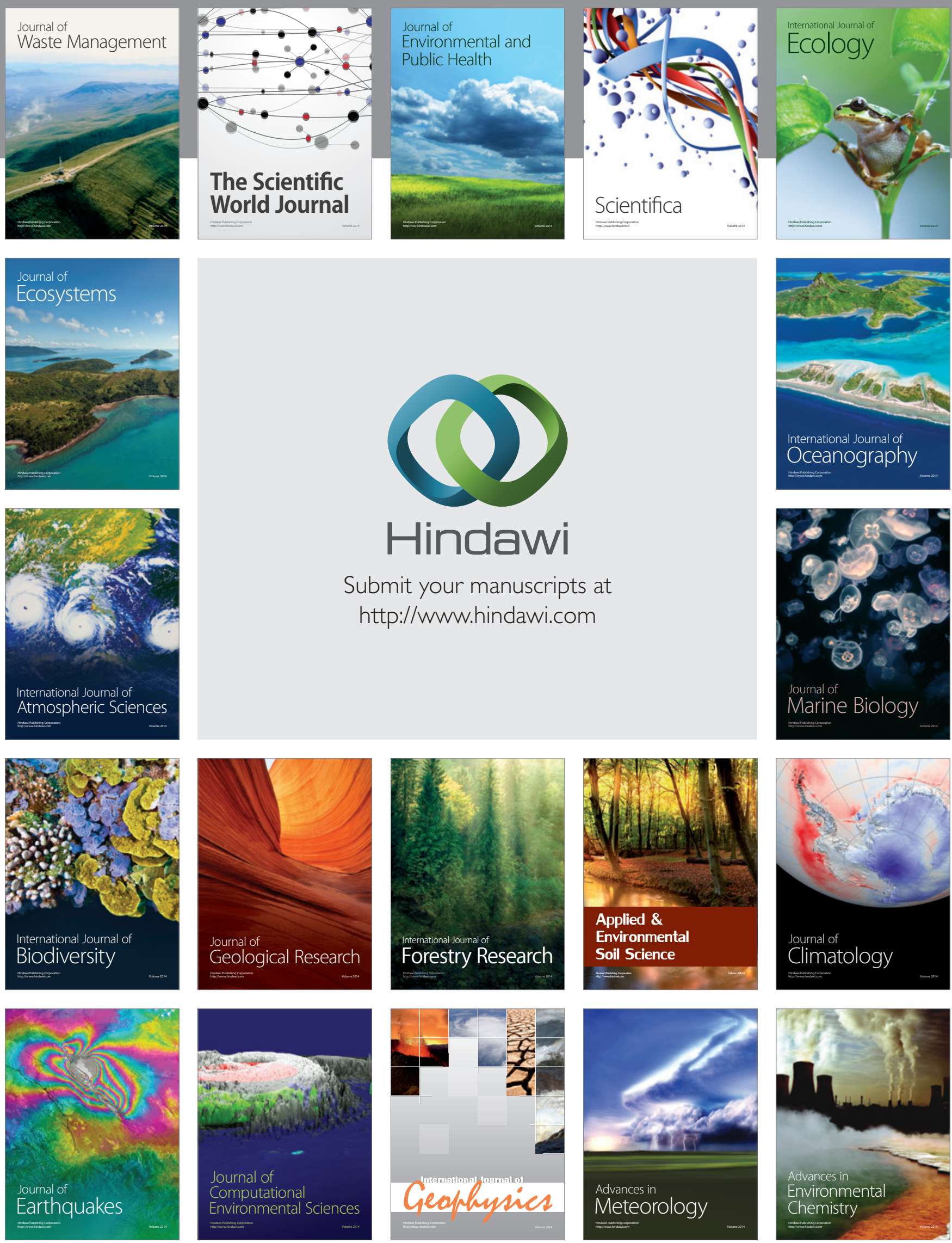